\title{
Temporal Variations of Baseflow Contribution to Epikarst spring Discharge in Gunungsewu Karst Area, Indonesia
}

\author{
Muhammad Naufal $^{1,2^{*}}$, Margaretha Widyastuti ${ }^{1,2}$, Ahmad Cahyadi ${ }^{1,2}$, Fajri Ramadhan ${ }^{2}$, Indra Agus Riyanto ${ }^{3}$, Khansa \\ Sitostratufana Arsy An nisa ${ }^{2}$, Tjahyo Nugroho Adji ${ }^{1,2}$, Eko Haryono ${ }^{1,2}$ \\ ${ }^{1}$ Karst Research Group, Faculty of Geography, Gadjah Mada University, Indonesia \\ 2 Environmental Geography Department, Faculty of Geography, Gadjah Mada University, Indonesia \\ ${ }^{3}$ Program on Planning and Management of Coastal Areas and Watershed, Faculty of Geography, Gadjah Mada University, Indonesia
}

\begin{abstract}
Flow moving slowly (infiltration), and known as steady flow or baseflow is the only supplier of water in underground flows in the form of karst fields during the dry season. Certainly, the character contribution of this flow plays a major role in supporting the supplier of clean water. Understanding related to the character of baseflow in detail has a very high urgency to be studied. This Research aims to do a temporal analysis of baseflow contributions on epikarst water springs in Gunungsewu Karst Area, Indonesia. The research takes place in Guntur Springs that occupy the hydrogeological subsystem. Data used in this Research includes flow data from Guntur Springs for one year. The method used in this Research is automated base flow separation by digital filtering. Results of the analysis show that baseflow contribution in Guntur Springs are between $79.57 \%$ and $93.96 \%$.
\end{abstract}

Keywords: Temporal Variations; Baseflow; Spring Discharge; Gunungsewu Karst Area.

\section{Introduction}

Karst is an international term [1] which is used to describe a particular landform [2] in the form of a unique morphology [3] and unique hydrology characteristics as well [4]. The existence of a unique karst environment is formed because of rocks' control that is soluble by water [5] such as carbonate rocks, evaporite and also quartzite. The karst landform is also very similar to the existence of caves and underground hydrogeological systems.

The existence of karst landform has a positive impact on the potential of their resources, including mineral resources, [6] tourism resources, as well as water resources. Pursing on the availability of water resources in the karst, it is known that the water needs of the world population is approximately $20-25 \%$ derived from water came from karst [2]. Therefore, the contribution of the character of the water flow to the karst landform plays a major role in supporting the lives of the surrounding communities in certain.

Flow type in aquifers consists of diffuse, fissure, and conduit [7-9]. The diffuse flow is a flow component that fills an underground river that flows through the cavity between the rock grains. This flow component is made up of infiltrated rainwater. Meanwhile, the fissure flow is a flow component that fills the underground river and its flow originates from the gap of carbonate rocks sizing $102-104 \mathrm{~mm}$. This flow is turbulent, especially when there is a flood. The conduit flow is a flow that fills the underground river, with a flow source that it is through a large size dissolving aisle.

Based on the definition of those three flow components, the flow that passes through a cavity between the rock grains which moves slowly is known as diffuse flow [10]. This flow component is the dominant water supplier on the underground river flow in the form of karst landform during the dry season [10, 11]. Thus, it can be seen that this flow component is always present in the dry season and in the rainy season, even though the amount is fluctuating.

In general, Gunungsewu karst is a representation of karst that develops in tropical environments [6] in which the area reaches $3.300 \mathrm{~km}^{2}$ including province of DIY (some of Gunungkidul District), Central Java (some of Wonogiri), and East Java (some of Pacitan District) (Fig. 1) $[9,12]$. The dominance of the Karst land of Gunungsewu uses is in the form of fields $(31.56 \%)$, and the rest is other land uses [13]. The research takes place in Guntur Springs which is part of the Gunungsewu karst located in the west part (hydrogeology subsystem). Administratively, the Guntur Springs are included in a Village called Girijati, Purwosari District, Gunungkidul Regency, D.I. Yogyakarta, Indonesia. The area of the Guntur Water Spring is $30.7 \mathrm{Ha}$ [14].

This research aims to know temporal variations of diffuse flow on Guntur Spring which is epikarst water springs in the area of Gunungsewu karst. This research is expected could give a full description related to the character of diffuse flow on epikarst water springs,

* Corresponding author: naufalmuhammad@mail.ugm.ac.id 
especially in a tropical karst area. 4.0 industrial revolution demands everything that takes place in this era of globalization with technological features. Thus, to characterize diffuse flow components, BFI + software is used. This software has a working principle by finding the value of digital filtering on the basis of the recession constant value in the event of a year-long hydrograph. By using this software, processing data with large capacity becomes easier and more effective.

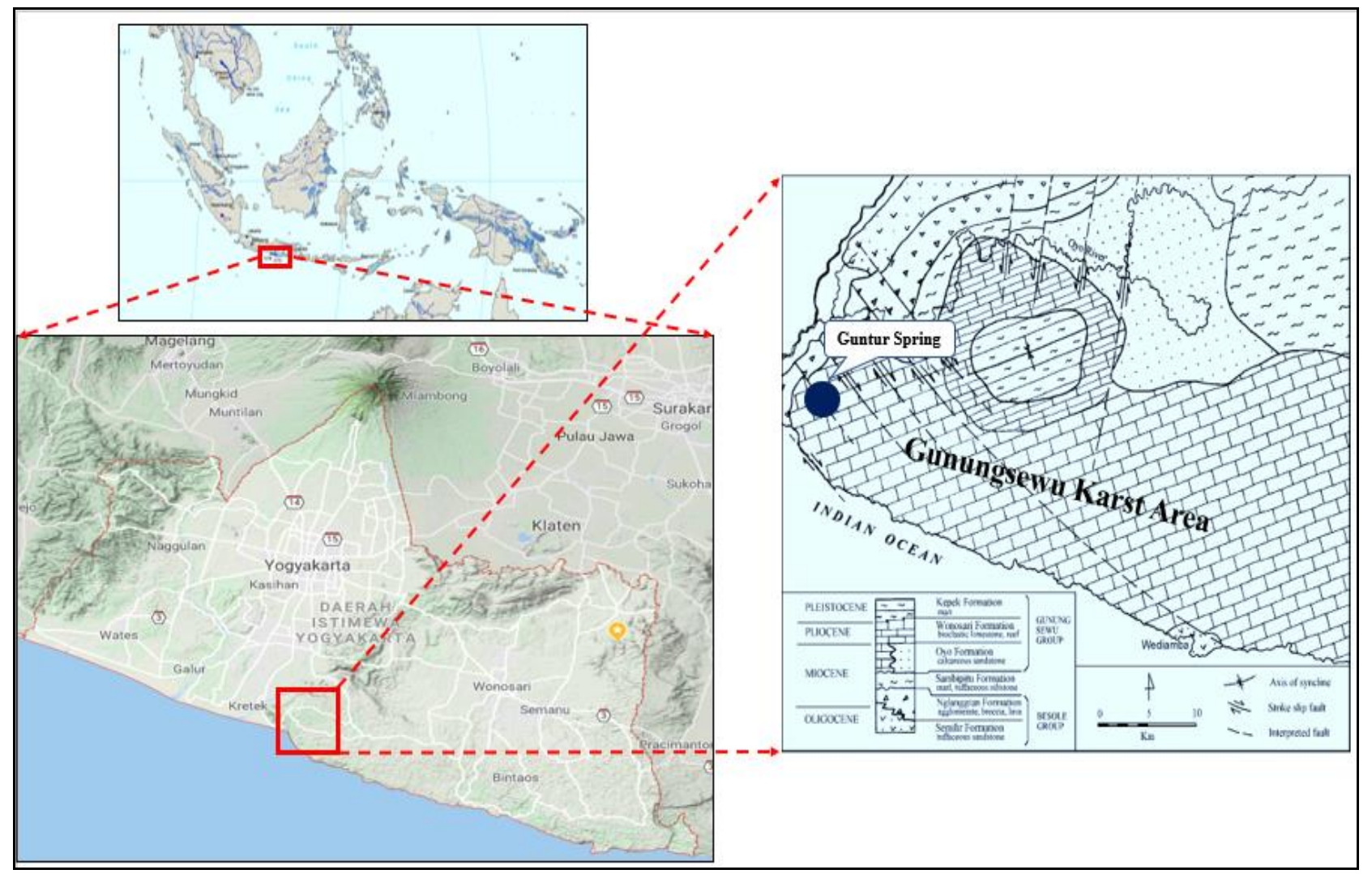

Fig. 1. Research location, Guntur Spring as part of Gunungsewu Karst area [15 with modifications]

\section{Methodology}

Research conducted is experimental research, which is to collect very much data (temporal). Then, it could be analyzed, elaborated with the existing theories, and it is concluded on a particular hypothesis. The main data collected in the research is the data of water level which is recorded through the water level data logger, and they converted to flowrate with a rating curve afterward. Water level data is collected for 1 year, starting in April 2018 until March 2019.

Measurements to represent low, medium and peak flowrate periods are carried out through direct measurements at the field (instantaneous measurement) for 29 times as a basis for making a flowrate curve and rating curve. Thus, it is known the relationship level between water level and flowrate which can be seen in the magnitude of the $\mathrm{R}$ value from the correlation results on the curve, and it is also obtained the formula for the relationship between water level and flowrate.

Furthermore, separation of the baseflow can be carried out based on the previously formed hydrograph of the flow. According to [16], he states that the separation of baseflow is a process of separation between baseflow components and the Run Off component. The method of baseflow separation is done by applying an automated method of baseflow separation by digital filtering [17]. The following is a formula of baseflow separation taken from automated baseflow separation by digital filtering.

$$
\mathrm{q}\left(\mathrm{bi}=\frac{(1-B F I \max ) \propto q b(i-1)+(1-a) \text { BFImaxqi }}{1-\alpha B F I \max }\right.
$$

$\mathrm{qb}_{(\mathrm{i})} \quad$ : Baseflow at time of $\mathrm{i}$

$\mathrm{qb}_{(\mathrm{i}-1)} \quad$ : Baseflow at time of $\mathrm{i}-1$

a : Baseflow Recession constant

$\mathrm{BFI}_{\max }$ : Maximum baseflow index ( 0.8 for porous material and perennial stream) [17]

\section{Results and Discussion}

\subsection{Spring Hydrograph}

The research conducted at the Guntur Spring is conducted for 1 year starting from April 2018 until the beginning of April 2019. The water level recording device in the Guntur Springs is set with a 10 -minute recording interval. The instantaneous flowrate and the water level measurements in the field were carried out 
29 times to obtain the equation through making a curve of the relationship between the water level and the flowrate called the rating curve. The following is the table of direct flowrate and water level measurement and also the result of the rating curve in Guntur Springs (Table 1 and Fig. 1).

Based on the results of the trend line between the value of water level and the amount of flowrate measured directly in the field, the $\mathrm{R}$ value of the rating curve is 0.9724 , meaning that the relationship between the two components is closer to 1 , that is, both have a strong relationship. The obtained equation is $y=944.62 x+24.04$. Based on these equations, the hydrograph of flow from the Guntur Water Spring can be presented afterward as follows in Fig. 3, which shows that water always flows from the rainy season to the dry season, even though there are significant flowrate fluctuations between the rainy and dry seasons.

Table 1. Direct Measurement on Water Level and Flowrate in the Fields

\begin{tabular}{|c|c|c|c|c|c|c|c|c|c|}
\hline \multirow{2}{*}{ No } & \multicolumn{2}{|c|}{ Measurement } & \multirow{2}{*}{$\begin{array}{c}\text { Water } \\
\text { level } \\
\text { (meter) }\end{array}$} & \multirow{2}{*}{$\begin{array}{c}\text { Discharge } \\
\text { (lit/sec) }\end{array}$} & \multirow{2}{*}{ No } & \multicolumn{2}{|c|}{ Measurement } & \multirow{2}{*}{$\begin{array}{c}\text { Water } \\
\text { level } \\
\text { (meter) }\end{array}$} & \multirow{2}{*}{$\begin{array}{c}\text { Discharge } \\
\text { (lit/sec) }\end{array}$} \\
\hline & Date & Time & & & & Date & Time & & \\
\hline 1 & $12 / 05 / 2018$ & 10.00 & 0.090 & 94.44 & 16 & $21 / 01 / 2019$ & 09.20 & 0.360 & 375.80 \\
\hline 2 & $12 / 06 / 2018$ & 09.00 & 0.098 & 92.24 & 17 & $22 / 01 / 2019$ & 14.08 & 0.350 & 368.92 \\
\hline 3 & $03 / 08 / 2018$ & 11.00 & 0.074 & 74.82 & 18 & $23 / 01 / 2019$ & 19.57 & 0.340 & 361.86 \\
\hline 4 & $04 / 09 / 2018$ & 10.00 & 0.109 & 87.16 & 19 & $13 / 02 / 2019$ & 02.55 & 0.322 & 341.80 \\
\hline 5 & $10 / 10 / 2018$ & 12.00 & 0.099 & 92.24 & 20 & $12 / 02 / 2019$ & 01.35 & 0.324 & 341.80 \\
\hline 6 & $04 / 11 / 2018$ & 12.30 & 0.045 & 95.46 & 21 & $01 / 03 / 2019$ & 19.45 & 0.378 & 385.19 \\
\hline 7 & $30 / 11 / 2018$ & 12.45 & 0.055 & 103.09 & 22 & $07 / 03 / 2019$ & 02.25 & 0.361 & 371.06 \\
\hline 8 & $22 / 12 / 2018$ & 11.25 & 0.150 & 190.24 & 23 & $16 / 03 / 2019$ & 01.50 & 0.412 & 430.44 \\
\hline 9 & $31 / 12 / 2018$ & 09.52 & 0.300 & 314.33 & 24 & $17 / 03 / 2010$ & 22.40 & 0.472 & 430.62 \\
\hline 10 & $05 / 01 / 2019$ & 10.38 & 0.320 & 342.45 & 25 & $18 / 03 / 2019$ & 07.30 & 0.464 & 430.44 \\
\hline 11 & $16 / 01 / 2019$ & 21.48 & 0.340 & 361.86 & 26 & $24 / 03 / 2019$ & 08.30 & 0.397 & 356.58 \\
\hline 12 & $17 / 01 / 2019$ & 23.02 & 0.370 & 382.70 & 27 & $06 / 04 / 2019$ & 09.50 & 0.257 & 259.26 \\
\hline 13 & $18 / 01 / 2019$ & 01.34 & 0.380 & 395.00 & & & & & \\
\hline 14 & $19 / 01 / 2019$ & 03.06 & 0.390 & 396.63 & & & & & \\
\hline 15 & $20 / 01 / 2019$ & 04.27 & 0.370 & 382.69 & & & & & \\
\hline
\end{tabular}

Sources: Field Measurement (2018-2019)

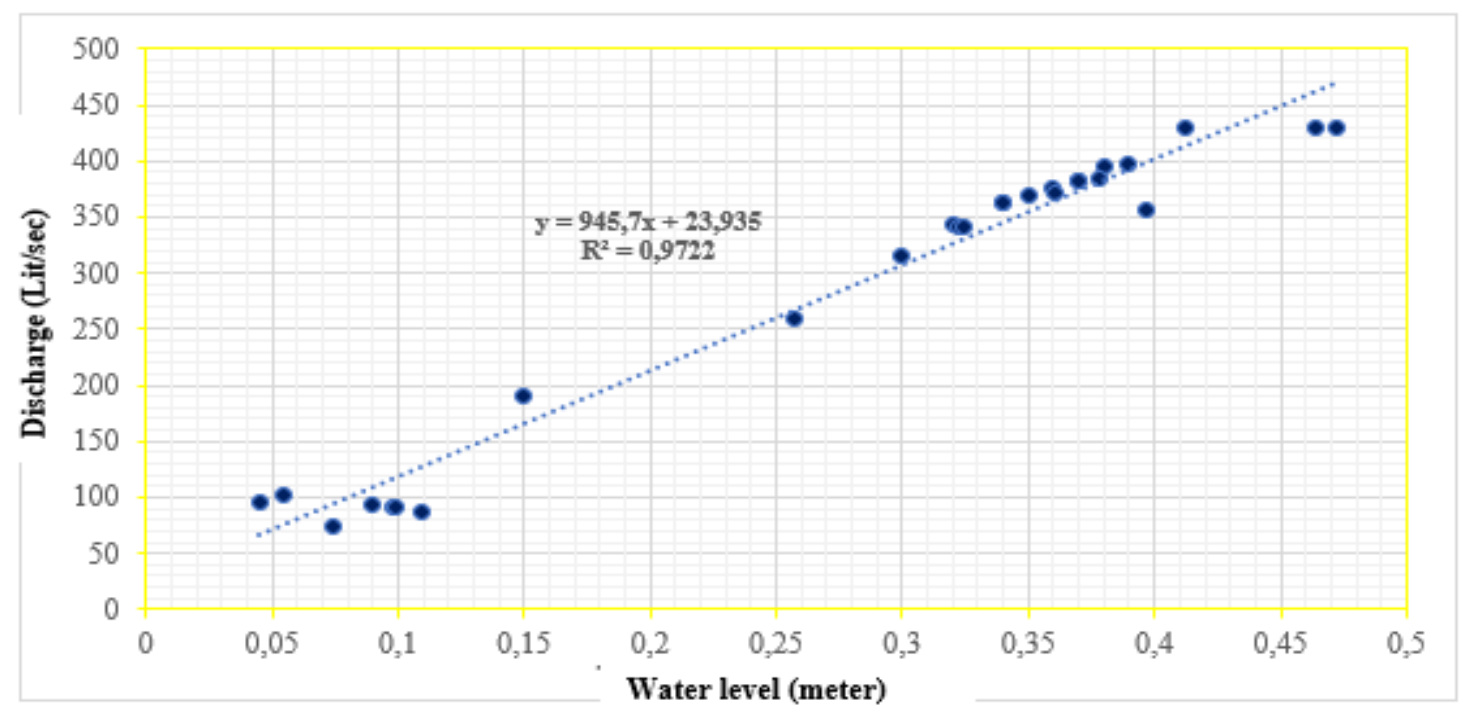

Fig. 2. Rating curve of Guntur Spring 


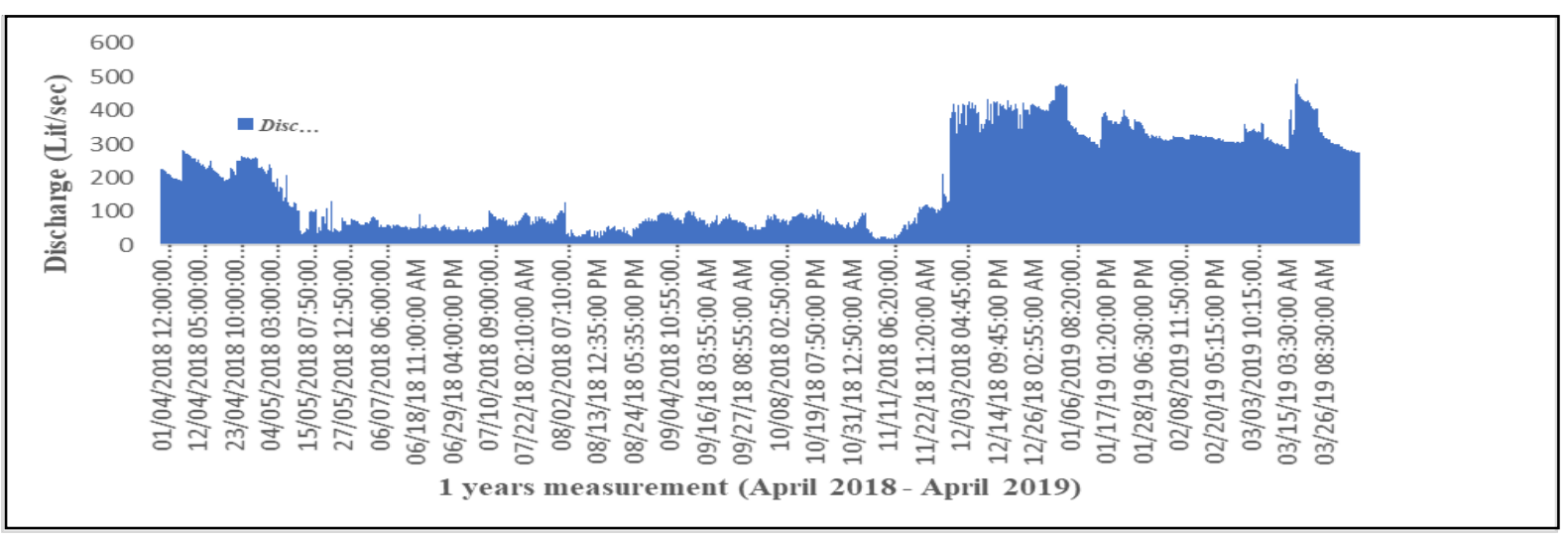

Fig. 3. Hydrograph of Guntur Spring

The appearance of Guntur Springs originates from the topographic cutting process caused by the existence of Opak fault [18] and cut north part of Karst Gunungsewu hill afterward [19], one of them is in the hydrogeology subsystem. The lowest and largest flowrate during the research each reached $7.56 \mathrm{lit} / \mathrm{sec}$ and $504.23 \mathrm{lit} / \mathrm{sec}$ sequentially, with an average of flowrate is 169.14 lit sec. The low amount of flowrate that occurs in the Guntur Springs become one of the characteristics of the existence of springs which are in the hydrogeology subsystem at Gunungsewu Karst. The position of the Guntur Springs at the top of the limestone coating makes it one of the causes of the layer above which acts as a thin layer of water storage so that its further impacts on groundwater deposits which are also limited (low) [20]. In line with the statement produced
[21], the spring of the hydrogeology subsystem is dominated by Epikarst Springs.

\subsection{Baseflow Characteristic of Guntur Spring}

Based on the hydrograph of flow that has been produced, 9 selected floods were obtained to identify the baseline characteristics of the Guntur Springs. Flood selection is assumed to represent conditions in the early rainy season until the end of the dry season. The following (Table 2) characteristics of the flow in the Guntur Springs include the amount of peak flowrate, flood category, flow time to impact (Tp), length of stay (Tb) and also base flow coefficient $(\mathrm{Kb})$.

Table 2. Characteristics of Hydrograph Components based on Selected Flood

\begin{tabular}{|c|c|c|c|c|c|c|}
\hline No. & Time & $\begin{array}{c}\text { Q max } \\
\text { (lit/sec) }\end{array}$ & Flood Category & $\begin{array}{c}\text { Tp } \\
\text { (Hours) }\end{array}$ & $\begin{array}{c}\text { Tb } \\
\text { (Hours) }\end{array}$ & Kb \\
\hline 1 & $07 / 04 / 2018$ & 279.56 & Medium & 1.16 & 205.82 & 0.990 \\
\hline 2 & $08 / 05 / 2018$ & 159.56 & Medium & 30.16 & 188.00 & 0.990 \\
\hline 3 & $22 / 12 / 2018$ & 423.56 & High & 3.60 & 117.60 & 0.999 \\
\hline 4 & $23 / 01 / 2019$ & 402.56 & High & 14.50 & 53.83 & 0.998 \\
\hline 5 & $18 / 03 / 2019$ & 504.23 & High & 2.16 & 169.83 & 0.999 \\
\hline 6 & $24 / 03 / 2019$ & 392.56 & High & 0.50 & 314.50 & 0.999 \\
\hline \multicolumn{7}{|r|}{ Average } \\
\hline
\end{tabular}

Sources: Data Processing (2019)

The results of data processing (Table 1) through the selected floods to identify characteristics of the flow in Guntur Springs produced an average time needed to reach a peak flowrate of 8.68 hours with the longest time of 30.16 hours and the fastest time for 0.5 hours. This condition is quite relevant to the ongoing flood conditions at that time, that is, when flooding in the low to moderate category, the time needed to reach the peak discharge is longer, and so is the reverse. The length of stay of water $(\mathrm{Tb})$ averages at 174.93 hours, with the longest time in the month when rain and flood occur in the high category, as evidenced by the longest time of 314.50 hours occurring in the flood on March 24, 2019.
Furthermore, the recession coefficient at the base of the Guntur Springs is an average of 0.990 , meaning that the value shows the slow release of flow components especially the baseflow in the Guntur Springs. Moreover, all these conditions reflect that the flow component in Guntur Springs is supported by a diffuse flow system that is quite dominating. Thus, it can be concluded, that during the dry season, the Guntur Springs continue to flow even though in low flowrate, which originates from the baseflow with slow release characteristics and the flow system is still in the form of seepage. The results of one-year baseflow separation processing are presented as follows (Fig. 4 and Table 3 ). 


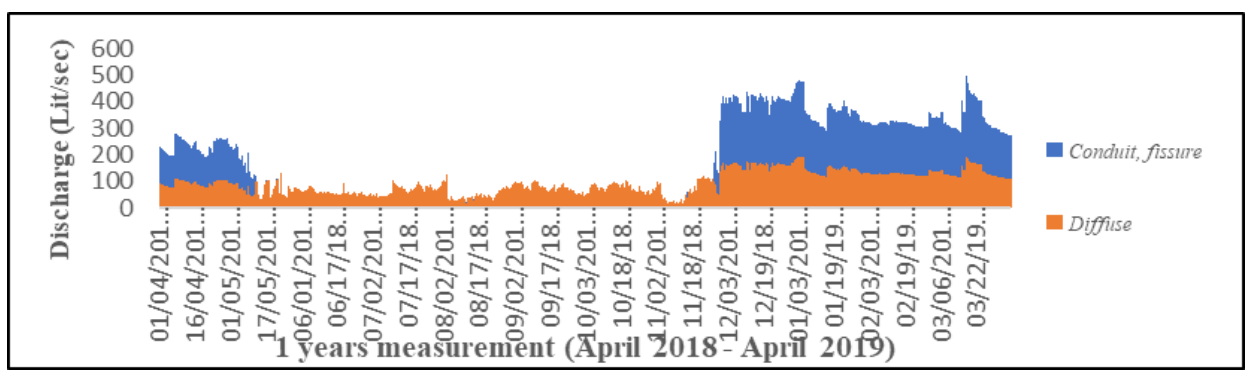

Fig. 4. Baseflow separation of Guntur Spring

Table 3. Monthly Baseflow Characteristic

\begin{tabular}{|c|c|c|c|c|c|}
\hline No. & Month & $\begin{array}{c}\text { Average of } \\
\text { discharge } \\
\text { (lit/sec) }\end{array}$ & $\begin{array}{c}\text { Average baseflow } \\
\text { (lit/sec) }\end{array}$ & $\begin{array}{c}\text { Average of } \\
\text { baseflow } \\
\text { proportion } \\
(\%)\end{array}$ & Season \\
\hline 1 & April '18 & 230.61 & 184.11 & 80.03 & Initial of dry season \\
\hline 2 & May'18 & 107.94 & 89.43 & 80.03 & Mid of dry season \\
\hline 3 & June '18 & 70.55 & 56.35 & 80.03 & Mid of dry season \\
\hline 4 & July '18 & 76.50 & 57.80 & 80.03 & Mid of dry season \\
\hline 5 & August '18 & 51.67 & 41.31 & 100 & Mid of dry season \\
\hline 6 & September ' 18 & 74.43 & 59.99 & 100 & Late of dry season \\
\hline 7 & October'18 & 70.55 & 56.35 & 100 & Late of dry season \\
\hline 8 & November '18 & 76.50 & 57.80 & 100 & Initial of rainy season \\
\hline 9 & December '18 & 366.26 & 290.07 & 79.57 & Initial of rainy season \\
\hline 10 & January '19 & 351.07 & 282.40 & 79.58 & Initial of rainy season \\
\hline 11 & February'19 & 311.82 & 249.76 & 79.59 & Mid of rainy season \\
\hline 12 & March ‘19 & 336.41 & 270.15 & 80.60 & Mid of rainy season \\
\hline 13 & April '19 & 277.72 & 224.27 & 80.59 & Late of rainy season \\
\hline \multicolumn{4}{|c|}{ Average } & 93.33 & \\
\hline
\end{tabular}

Sources: Data Processing (2019)

Fig. 4 shows the proportional magnitude of the baseflow over 1 year. Further in table 3 presents the monthly mean baseflow that occurs with the average of baseflow proportion each month. How long the range average of baseflow that occurs starts from 41.31-290.07 lit/sec. Based on the results of data processing, the basic value of the baseflow is dominantly greater in the month which is included in the rainy to the late rainy season than in the dry season. This condition certainly occurs because springs are likely to be more massive in getting water supply during the rainy season, different from conditions in the dry season.

The average proportion of baseflow per month, the month classified as the dominant dry season has a greater proportion than in the rainy season (May-August 2018). This condition certainly occurs because the flow is more dominant in the dry season even the whole consists of only components of the base flow proportion, without any contribution of the direct flow (conduit). While, it is different when the rainy season takes place, the proportion of the baseflow will certainly be lower because of the contribution of the direct flow component. Thus, the proportion of baseflow becomes larger in the dry season than the baseflow proportion in the rainy season. As for supporting this statement, it can further be understood through the separation of the baseflow from selected floods in 1 year as follows (Table 4 and Fig. 5).

Table 4. Baseflow Separation of Selected Flood Events

\begin{tabular}{|c|c|c|c|c|c|}
\hline No. & $\begin{array}{c}\text { Selected flood } \\
\text { event }\end{array}$ & $\begin{array}{c}\text { Peak discharge } \\
\text { (lit/sec) }\end{array}$ & Flood category & Baseflow (lit/sec) & $\begin{array}{c}\text { Baseflow } \\
\text { proportion (\%) }\end{array}$ \\
\hline 1 & $07 / 04 / 2018$ & 279.56 & Low & 224.65 & 80.36 \\
\hline 2 & $08 / 05 / 2018$ & 159.56 & Low & 128.45 & 80.50 \\
\hline 3 & $22 / 12 / 2018$ & 423.56 & High & 338.05 & 79.81 \\
\hline 4 & $23 / 01 / 2019$ & 402.56 & High & 321.25 & 79.80 \\
\hline 5 & $18 / 03 / 2019$ & 504.23 & High & 370.88 & 73.55 \\
\hline 6 & $24 / 03 / 2019$ & 392.56 & High & 313.25 & 79.79 \\
\hline \multicolumn{7}{|c|}{ Average } & & 78.97 \\
\hline
\end{tabular}


The baseflow events that occur range from 50.05$370.88 \mathrm{lit} / \mathrm{sec}$. The existence of a fairly large range of values between the baseflow in the selected flood March 17,2019 , and the others is because there is a savanna cyclone that occurs and impacts the emergence of rain with a long intensity and with sufficiently high rainfall at that time, resulting significant increase in water level and further on the abundance of the baseflow. The proportion of the baseflow, almost the same as the average monthly yield, in selected floods the dominance of the proportion of baseflow is greater in the dry season, which in table 4 is classified with the category of moderate to low flooding.
Baseflow contributions, as discussed earlier, have a greater proportion in the dry season than during the rainy season. Figure 5 represents a block diagram of baseflow separation at each flood event. During the rainy season, the direct flow has a greater contribution so that it reduces the proportion of the basic flow component. Shown from the left to the right diagrams, which proves that the more the right of the block diagram, the flow of baseflow proportions decreases and the proportion of the direct flow (conduit) increases. The most significant decrease in baseflow contribution with the largest direct flow contribution can be seen in the selected flood diagram block that occurred on the 17th March 2019 when the cyclone savanna occurred.

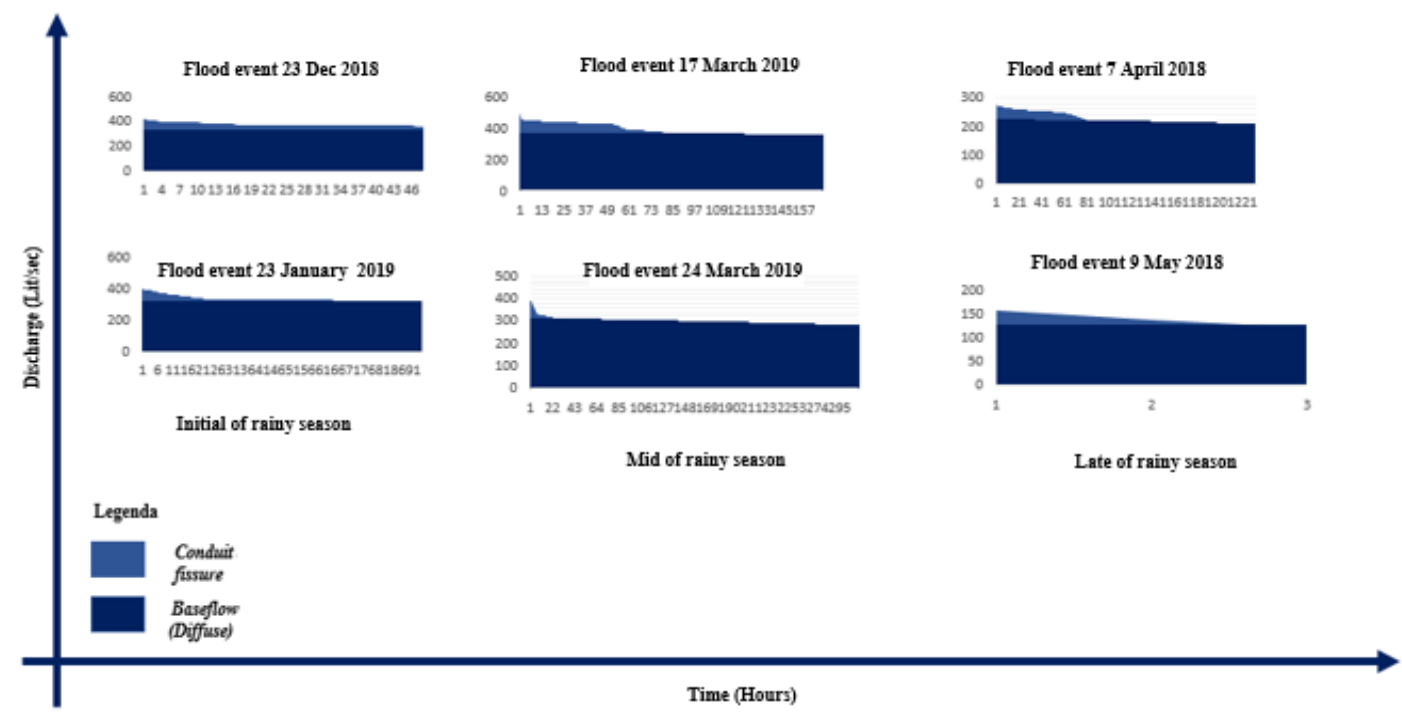

Fig. 5. Selected Flood Graphic of Baseflow Separation Event

\section{Conclusion}

The lowest and largest flowrate during the research each reached $7.56 \mathrm{lit} / \mathrm{sec}$ and $504.23 \mathrm{lit} / \mathrm{sec}$, with an average flowrate of $169.14 \mathrm{lit} / \mathrm{sec}$. The low amount of flowrate that occurs in the Guntur Springs is one of the characteristics of the emergence of springs which are in the hydrogeology subsystem at Gunungsewu Karst. The average time needed to reach the peak discharge for 8.68 hours with the longest time of 30.16 hours and the fastest time for 0.5 hour. This condition is quite relevant to the ongoing flood conditions at that time, that is, when flooding is in the low to moderate category, the time needed to reach the peak flowrate is longer, and so is the reverse. The length of stay of water $(\mathrm{Tb})$ averages at 174.93 hours, with the longest time in the month when rain and flood occur in the high category, as evidenced by the longest time of 314.50 hours occurring in the flood on March 24, 2019. Furthermore, the recession coefficient at the base of the Guntur Springs is an average of 0.997 , meaning that the value shows the slow release of flow components especially the baseflow in Guntur Springs. Furthermore, all these conditions reflect that the flow component in the Guntur Springs is supported by a diffuse flow system that is quite dominating.
Baseflow event range that occurs starts from 41.31 $290.07 \mathrm{lit} / \mathrm{sec}$. Based on the results of data processing, the basic value of the baseflow is dominantly greater occurring in the month which is included in the rainy to a late rainy season than in the dry season. This condition certainly occurs because springs are likely to be more massive in getting water supply during the rainy season, different from conditions in the dry season.

During the rainy season, the direct flow has a greater contribution so that it reduces the proportion of the baseflow component. Shown from the left to the right diagrams, which prove that more to right side of the block diagram, the flow of the baseflow proportions decreases, and the proportion of the flow conduit increases. The most significant decrease in baseflow contribution with the greatest direct flow contribution can be seen in the selected flood diagram block that occurred on March 18, 2019, when the cyclone savanna occurred. Results analysis to show that contribution diffuse flow at Guntur Springs is between $79.57 \%$ and up with $100 \%$.

This research was made possible by funding from the Final Assignment Recognition Grant, Gadjah Mada University. The writing team would like to thank the karst research group which has helped a lot during the field season until this journal was written. The writing 
team also thanked the Faculty of Geography, Gadjah Mada University for allowing this research to be carried out.

\section{References}

1. H. Fatchurohman, Characterization and Management of Karst Drainage System based on Karst Hydrograph Analysis in Gunung Sewu Karst Area. Thesis (2017)

2. D.C. Ford, P.W. Williams, Karst Hydrogeology and Geomorphology, Chichester: Wiley (2007)

3. P. Milanovic, Optimal Water Management Prerequisite for Regional Socio-Economic Development in The Karst of The South-Eastern Dinarides, International Association of Hydrogeologists Selected Papers : Karst without Boundaries (2015)

4. I. Riyanto, A. Cahyadi, T.A. Adji, E. Haryono, M. Widyastuti, R.F. Agniy. A.F. Wilda, N. Rahmawati H. Baskoro, Analysis of Connectivity and Characterization of Pelorongan by Tracing Test on Epicarst Springs Roast Sub-Systems, Gunungsewu Karst Region, Pekan Ilmiah Tahunan Perhimpunan Ahli Airtanah Indonesia (Paai), (2015)

5. V.P. Beynen. Karst Management, New York: Springer (2011)

6. T.N. Adji, E. Haryono, S. Woro, Karst Area and Its Development Prospects in Indonesia, Seminar PIT IGI di Universitas Indonesia Jakarta (1999)

7. W.B. White, Conceptual Models for Carbonate Aquifers, Ground Water 7(3) (1969)

8. T.C. Atkinson, Diffuse Flow and Conduit Flow in Limestone Terrain in The Mendip Hills, Somerset (Great Britain), Journal of Hydrology 35, 95-110 (1976)

9. T.C. Atkinson, Present and Future Directions in Karst Hydrogeology, Ann. Soc. Geoi. Belgique 108, 293-296 (1985)

10. T.N. Adji, The Separation of the Upper Baseline Flow of the Bribin River at Aliran Gua Gilap, at Karst Gunung Sewu, Gunungkidul, Yogyakarta, Jurnal Geologi Indonesia 6(3), 165-175 (2011)

11. T.N. Adji, E. Haryono, H. Fatchurohman, R. Oktama, Diffuse Flow Characteristic and Their Relation to Hydrohemistry Conditions in The Petoyan Spring, Gunungssewu Karts, Java, Indonesia, Geosciences Journal DOI 10.1007/s12303-015-0048-8 (2015)
12. E. Haryono, Introduction to Gunungsewu Karst. Field Guide of Asian Trans-Disciplinary Karst Conference. Yogyakarta: Karst Researc Group, Faculty of Geography, Universitas Gadjah Mada. Haryono E, Day M 2004 Landform differentiation within the Gunung Kidul Kegelkarst, Java, Indonesia Journal of Cave and Karst Studies 662 62-69 (2011)

13. P. Wijayanti, E. Haryono, P. Hadi, Water Balance in Epikarst: Case study of Kakap Springs, the Eastern Karst of Gunungsewu, 1st UPI International Geography Seminar DOI 10.1088/1755-1315/145/1/01210.1088 (2017)

14. M. Widyastuti, I.A. Riyanto, M. Naufal, F. Ramadhan, N. Rahmawati, Water Catchement Area Analysis of Guntur Karst Spring, Proceeding. The 2nd International Conference on Environmental Resources Management in Global Region (2018)

15. S.B. Kusumayudha, Gunungsewu Hydrogeology System, Prosiding Sumberdaya Geologi Daerah Istimewa Yogyakarta dan Jawa Tengah. Ikatan Ahli Geologi Indonesia (IAGI) Pengda DIY-Jateng, 130 - 141 (2002)

16. E.F. Schulz, Problems in Applied Hydrology. Water Resources Publication (1976)

17. K. Eckhardt, How to Construct Recursive Digital Filters for Baseflow Separation, Hydrological Processes 19, 507-515 (2005)

18. S. Notosiswoyo, S.B. Kusumayudha, Hydrogeology of The Gunungsewu Karstic Area, Central Java, Indonesia: A Conceptual Model, Proceeding of Ninth Regional Congress on Geology, Mineral and Energy Resources of South East Asia. Kuala Lumpur (1998)

19. A. Cahyadi, I. Riyanto, M.R. Irshabdillah, F. Firizqi, Inventory and Characterization of Alogenic River Flow System in Gunungsewu Karst Area, Gunungkidul Regency, Laporan Hibah Penelitian Dosen Fakultas Geografi UGM 2018 (2018b)

20. A. Cahyadi, A.I. Riyanto, S.F. Lestari, N. Listyaningrum, Increasing the Capacity of the Girijati Village Community, Purwosari District, Gunungkidul Regency in the Conservation of the Karst Area, Laporan Hibah Pengembangan Program Pengabdian Kepada Masyarakat Fakultas Geografi UGM 2018a (2018)

21. E. Haryono, D. Barianto, A.H. Cahyadi, Guide to Hydrogeological Field Activities in the Gunung Sewu Karst Region, Yogyakarta : PIT-PAAI (2017) 